\title{
The epidemiology of schizophrenia and other common mental health disorders in the English-speaking Caribbean
}

\author{
Frederick W. Hickling ${ }^{1}$
}

Suggested citation

Hickling FW. The epidemiology of schizophrenia and other common mental health disorders in the English-speaking Caribbean. Rev Panam Salud Publica. 2005;18(4/5):256-62.

ABSTRACT Objective. To report on the epidemiology of schizophrenia and other common mental health disorders in the English-speaking Caribbean.

Methods. The MEDLINE, MEDCARIB and West Indiana electronic databases were searched with the phrases Caribbean AND psychiatry OR mental OR suicide, and items with specific reference to epidemiology were culled and reviewed.

Results. The age-corrected incidence rate for schizophrenia per 10000 is 2.09 in Jamaica, 2.2 per 1000 in Trinidad, and 2.92 in Barbados. These rates are lower than the incidence rates reported for white British people, and significantly lower that the 6-to 18-fold higher risk ratio incidence reported for African Caribbeans living in Britain. A comparative diagnostic study carried out in the United Kingdom (UK) suggests that misdiagnosis plays a significant role in this difference. Relatively low incidence figures for affective disorders, anxiety states, suicide and attempted suicide have been reported for Jamaica, Trinidad, and Barbados.

Discussion. Most published epidemiological studies of Caribbean populations center on schizophrenia, because of the startling findings of a large increase in risk ratios for African Caribbean people living in England compared to the white native British people. The etiological evidence is shifting toward factors of racism and social alienation experienced by black people in the UK, and to misdiagnosis by white British psychiatrists. Studies of the role of colonial enslavement and social engineering raise the etiological possibility of a role for social and structural community organization in the genesis of schizophrenia. The Caribbean thus represents a rich crucible for research in the epidemiology and etiology of mental health disorders.

Key words Epidemiology; mental health disorders; English-speaking Caribbean.

Professor of Psychiatry, Department of Community Health and Psychiatry, Faculty of Medical Sciences, University of the West Indies. Send correspondence and reprint requests to Frederick W. Hickling, Department of Community Health and Psychiatry, Faculty of Medical Sciences, University of the West Indies, Mona, Kingston 7, Jamaica; telephone: (876) 927 2492, (876) 702 2095; fax: (876) 927 2116; e-mail: frederick.hickling@uwimona. edu.jm

\section{INTRODUCTION}

\section{Colonization and the subsequent Diaspora}

The Caribbean represents different things to different people. To the tourist it represents an island paradise, with white sand beaches and idyllic blue seas. However, to many natives the Caribbean is a place to emigrate from, an environment of poverty and dissatisfaction, and a place to flee from. After five centuries of European 
colonization, the twenty-first-century Caribbean is a composite of the British West Indies, the Spanish Caribbean (now regarded as part of Latin America), the French Caribbean (still politically part of mainland France), the Dutch Antilles, and the fragments still "owned" by the United States of America (Puerto Rico and the U.S. Virgin Islands).

Initial patterns of migration to the Caribbean saw European settlers move into the West Indies, a massive trade of Africans to fuel the West Indian plantations, and-following the abolition of slavery - the immigration of indentured labor from India and China. By the beginning of the twentieth century, the dynamics of colonialism in the Caribbean had triggered huge waves of secondary immigration, which saw mass migrations of poor Black people to Central America, North America and the United Kingdom in search of employment. The numbers of Caribbean people in this Diaspora easily doubles the estimated population of 25 million people in the Caribbean.

\section{Evolution of the concept of psychopathological nosology}

Mental illnesses in African and indigenous people were not originally recognized by the European colonizers. It had been suggested (1) that mental illness was rare among the savage tribes of Africa, the slaves of the West Indies and the Welsh and Irish peasants, but common in the civilized nations of Western Europe as a product of the stress of civilization. Initial psychopathological nosology in relation with African slaves was based on racist and colonialist viewpoints. Drapetomania was defined as "a mental disease of slaves which caused Blacks to have an uncontrollable urge to run away from their masters, the treatment of which was whipping the devil out of them" (2). Following the abolition of slavery in the nineteenth century, European colonialist attitudes continued to shape psychopathological nosology and to dominate psychology with a contemporary modernist and postmodernist worldview (3).

\section{Cultural and semantic considerations and terminology}

Sashidharan and Francis (4) have concluded that attempts at an epidemiological and etiological analysis from current Eurocentric perspectives will simply reinforce the racist bias and continue to engender illusions that often pass for present-day scientific investigation. Hutchinson and McKenzie (5) analyzed the prefix and the suffix Caribbean in the context of the term "AfroCaribbean" used in contemporary epidemiological studies, and questioned whether a term which describes such a diverse group of individuals and cultures could be useful as a scientific variable. They concluded that using the term "Afro-Caribbean" perpetuates and reinforces stereotypes and ignorance.

\section{Aims of the study}

This paper will focus on the epidemiology of common mental health disorders in the English-speaking Caribbean diaspora. The paucity of published material from the smaller territories has necessitated particular attention to findings from the larger islands of Jamaica, Trinidad and Barbados.

\section{METHODS}

The MEDLINE, MEDCARIB and West Indiana electronic databases were searched with the phrases Caribbean AND psychiatry OR mental OR suicide.

Abstracts and titles of the documents returned were visually scrutinized for relevance to Caribbean mental health in general, and, more specifically, to epidemiology. Documents meeting the relevance criteria were retrieved and their full text (when available) was reviewed. Articles relevant to the overall thesis of the present study were included in the analysis. Publications on substance abuse and psychogeriatrics were excluded.

\section{RESULTS}

Thirty-one papers on the epidemiology of mental health disorders were located in the database search. The majority of these were from Jamaica. A significant number of publications were identified on psychiatric disorders (particularly on schizophrenia and psychosis) in African Caribbean people in the UK. The results presented here will focus principally on these areas.

\section{Schizophrenia}

The earliest epidemiological report on schizophrenia in the Caribbean was from Jamaica (6), and indicated that the annual population incidence rate was 150 per 100 000. Burke (7) confirmed this finding, and reported an annual incidence rate of 136 per 100000 . Both studies were based on mental hospital admission rates, and it is likely that these studies failed to access the total number of admissions for the island. A study of psychiatric admissions to private and public hospitals across Jamaica (8) reported that the incidence rate of schizophrenia had fallen from 69 per 100000 in 1960 to 35 per 100000 in 1990. This decline was attributed to earlier case finding and improved outpatient treatment and outcomes provided by the Community Psychiatric System, which had been introduced in the island in the early 1970s.

The reportedly low admission rates in Jamaica call into question the consistently reported higher rates of schizophrenia in African Caribbean populations living in England compared to white people. These studies indicated a risk ratio for schizophrenia more than threefold to sixfold as high as that in the white indigenous population (9), and up to eighteen times as high for the children of African Caribbean immigrants (10). Many of these studies, however, have methodological flaws and their findings have been challenged (11).

It has been suggested that these high rates may be due, at least in part, to misdiagnosis by white British psychi- 
atrists. This hypothesis was tested at the Maudsley Hospital in the UK. In collaboration with Robin Murray, Director of the Institute of Psychiatry at the Maudsley Hospital, we selected 66 patients: 24 were white, 29 were black African Caribbeans, and 13 were blacks from other countries of origin (12). As a black Jamaican psychiatrist, I conducted my standard clinical assessment-which included the Present State Examination (PSE) (13)_of these patients. The diagnoses of the Jamaican psychiatrist were compared to the case note diagnoses by British psychiatrists, and also to diagnoses based on the PSE-Catego criteria.

Of 29 African and African Caribbean patients who received a diagnosis of schizophrenia, the diagnoses of the British and Jamaican psychiatrists agreed in $16(55 \%)$ and disagreed in $13(45 \%)$. The interrater reliability was poor (kappa 0.45). The PSE-Catego system diagnosed a larger proportion of persons as having schizophrenia than the Jamaican psychiatrist (chi squared $=3.74 ; P=0.052$ ). Agreement between the Jamaican psychiatrist and his UK counterpart over which patients were schizophrenic was poor. Furthermore, the PSE-Catego system overestimated the rates of schizophrenia in both the African Caribbean and white populations in the UK.

One component of this research remained unpublished in the UK. When the diagnoses of the 24 white patients were compared, the diagnoses of the British and Jamaican psychiatrists agreed in $18(75 \%)$ and disagreed in 6 (25\%) patients, with a much higher interrater reliability (kappa 0.66). The findings of the Maudsley study suggested that diagnostic agreement between the Jamaican and the British psychiatrists was much more reliable when the patients were white than when they were black.

In a study of the incidence of schizophrenia in Jamaica based on the first contact with the services, and in which a standardized diagnostic instrument (the PSE) was used to identify cases, Hickling and Rodgers-Johnson (14) demonstrated an age-corrected inci- dence rate of schizophrenia of 2.09 per 10 000. The authors suggested that the findings of the British studies for blacks in the UK either reflected a methodological artifact or were due to major etiological factors specific to African Caribbean people living in the UK. For the island of Trinidad (population 1.2 million) in the southern Caribbean (15), a 1-year study of admissions in a defined catchment area with a population of 100000 found that the admission rate for mental illness was 5 per 1000 , of which schizophrenia accounted for $2 \%$. A more recent report (16) based on first contacts for schizophrenia used the standardized PSE for diagnostic evaluation, and reported an incidence rate of 2.2 per 1000 , a figure within the range of incidence values previously found for Jamaica. In a similar study in Barbados (17), the incidence rate for schizophrenia was reported to be 2.92 per thousand, a figure that confirmed earlier findings for Jamaica and for Trinidad.

The age-corrected prevalence rate of schizophrenia in Jamaica (population 2.5 million) based on a 1-year case register study was found to be 3.1 per 1000 (18), which is within the range of figures reported in studies in the USA, UK and Italy (19).

There have been few documented studies of the prevalence of schizophrenia for African Caribbeans in the Caribbean or elsewhere. Cochrane and Bal (20), in a study of England and Wales with data from the Mental Health Enquiry, reported a prevalence rate of 30.7 per 1000 for African Caribbeans and 8.7 for the native white population. Thus the rate reported for Jamaicans at home is one tenth the rate reported by Cochrane and Bal for African Caribbean immigrants in England and Wales, and somewhat less than one third of the prevalence in native whites.

The prevalence rate for schizophrenia in a case register study in the Caribbean island of Dominica (21) was reported to be 11.8 per 1000 based on the diagnostic criteria of the 9th edition of the International Classification of Diseases (ICD-9), and 7.8 per 100000 based on the criteria of the Diagnostic and Statistical Manual, edition III. These rates are somewhat higher than the Jamaican rates, although they are within the range of values found for native whites in the UK. Caution is urged in the interpretation of prevalence rates from very small Caribbean islands with populations under 50 000, as the significant migration of people from the smaller island states of the Caribbean to other larger Caribbean territories and other parts of the world considerably reduces the population used to calculate prevalence rates. In addition, it is a common practice for immigrants from small island states who develop a schizophrenic illness in other parts of the Caribbean and the world to be returned to their homeland for management of their illness. These factors tend to increase the numerators and decrease the denominators in prevalence calculations in these small island territories, thereby significantly inflating the rates.

Recent epidemiological studies in the Caribbean which show that the rates of schizophrenia in those countries are no higher than for white people in Britain suggest that genetic predisposition alone cannot account for the high reported rates of schizophrenia in African Caribbeans in the UK. A study examining the risk of schizophrenia in first-degree relatives of African Caribbean and white schizophrenic patients (22) reported that the parents of both groups had similar risks, whereas the siblings of African Caribbean patients born in the UK were at significantly greater risk than any other group of relatives. In a similar study (23) the morbidity risk for schizophrenia in the siblings of a second-generation African Caribbean proband with psychosis was seven times as great as for their white counterparts, whereas the siblings of the first-generation proband showed no such increase. It was concluded that there are environmental factors acting specifically on the second-generation African Caribbean population in the UK that increase the likelihood of psychotic illness.

A study of black mentally ill emigrants who returned to Jamaica (24) 
reported that the vast majority of patients who had developed schizophrenia had done so after emigrating to North America or Europe, and not before leaving or after returning to Jamaica. These emigrants also had much higher rates of schizophrenia than matched Jamaican control patients who had never emigrated. It was also shown that a statistically significant number of these patients were from a higher socioeconomic class before emigrating from Jamaica, and had taken a step down in social class by emigrating. In another study (25) of 222 returned mentally ill Jamaican emigrants seen in the period from 1979 to 1995,72 patients received a diagnosis of schizophrenia compared to 44 control patients $(P<0.01)$, although $90 \%$ of the patients had developed schizophrenia while they were immigrants in North America and Europe. There was no statistically significant difference in the numbers of patients who had developed schizophrenia in North America and Europe compared with controls. Regardless of whether the cause of this condition is biological, neurodevelopmental, or due to harsh and racist environments in first-world metropolises, there is increasing evidence (26) that black Jamaicans are much more susceptible to this condition in Europe and North America than in their own country. In a study (27) of a range of retroviruses in a cohort of Jamaicans with schizophrenia, no evidence could be found of a viral etiology for this condition in Jamaicans.

Another study (28) of a sample of 49 white mentally ill immigrants to Jamaica compared their diagnoses with those of a sample of mentally ill Jamaicans matched for age, sex and social class who had never emigrated. The study showed that white mentally ill immigrants to Jamaica did not develop schizophrenia at a higher rate than native-born residents. This result runs counter to the consistent finding of increased rates of schizophrenia in immigrant populations. The study in fact suggests that the rate of mental illness in white immigrants to Jamaica was not increased in comparison to matched Jamaican controls, which is also unusual for an immigrant population. White mentally ill immigrants to Jamaica were shown to belong to a significantly higher socioeconomic class (UK Registrar General's Classification of socioeconomic class by occupation) in Jamaica than their parents in their country of origin. It was suggested that for this cohort of immigrants, migration created a condition of immediate and marked upward social mobilitya condition which rarely if ever occurs for immigrants, whether black or white, to white first-world countries. The parents of Jamaican control subjects belonged to a significantly higher socioeconomic class than the parents of white immigrant patients, suggesting that immediate upward social mobility in the white immigrant cohort was a unique factor for that group. The hypothesis was therefore advanced that the political and economic system in black post-colonial countries like Jamaica protects white immigrants from the social stress of immigration, which often causes schizophrenia in migrant groups in predominantly white societies. It was suggested that the converse may also be true, namely, that the socioeconomic and political structure of white first-world countries may contain built-in conditions which predispose both black and white migrants to downward social mobility, creating a psychosocial stress factor which predisposed to the development of schizophrenia.

In an important review, Sharpley et al. (29) suggested that African Caribbean people resident in England are at a higher risk of developing an illness that meets the operational criteria for schizophrenia than the populations in the countries of origin, or the white English indigenous population. They raised the question whether the threshold for qualifying for a diagnosis of schizophrenia is set lower for the African Caribbean population, and suggested further that African Caribbeans resident in England experience an excess of a "type" of psychosis which may present phenomenologically as either schizophrenia or mania. They concluded that African Caribbean patients in England may be more at risk of developing this condition because of their experience of social disadvantage and racial discrimination in the UK, and that this situation resulted in threats to their everyday social life and challenges to their self-perception and identity.

\section{Other mental health disorders}

The paucity of published material on other psychiatric conditions in the English-speaking Caribbean makes a thorough review impossible. Hickling (8) reported an extremely low admission rate for affective psychosis of 12 per 100000 in Jamaica. A study in Trinidad (15) reported an annual agecorrected admission rate of 0.8 per 1000 for affective psychoses, thus adding support to the Jamaican findings of a low rate of affective psychoses in the Caribbean region. This is in sharp contrast to the findings of high incidence rates for mania in blacks in the UK (30). In a more recent study in Jamaica (31), data were collected from a national mental health case register from the Community Mental Health Service, the Bellevue Mental Hospital and the University Hospital of the West Indies. The prevalence rates for affective psychoses were established on the basis of total population data for that year. The period prevalence rate for mania and manic-depressive psychosis was 0.16 per 1000 , and the agecorrected (15-55 years) prevalence rate was 0.23 per 1000 .

Relatively little is known about nonpsychotic disorders such as anxiety and depression in Caribbean people. An analysis of annual in- and outpatient admissions to the University Hospital psychiatric unit in Jamaica in 1971 (32) found that of a cohort of 587 new patients seen, 135 patients $(23 \%)$ were diagnosed as suffering from depression and $72(12 \%)$ were diagnosed as suffering from anxiety states. The island-wide first admission study (8) reported a low admission rate for depression in public sector facilities, but for the private and university facilities the admission rate was considerably higher. Goldberg and Huxley (33) in- 
dicated that of every 10 general practice attendees with psychiatric morbidity detected by the General Health Questionnaire (GHQ), six were diagnosed as having a psychiatric problem by their general practitioner. A study (34) using the GHQ in Kingston, Jamaica indicated that 32 of 98 patients $(33 \%)$ from a general practice were found to have a nonpsychotic psychiatric problem, while another study (35) also found high numbers of patients with nonpsychotic psychiatric problems among university students in Jamaica.

\section{Suicide and attempted suicide}

Mahy (36) reported a suicide rate in 1989 of 2.3 per 100000 in Barbados and 2.8 per 100000 in the Bahamas. Burke (37) reported a suicide rate of 7 per 100000 in Trinidad in the early 1970s, while an earlier study (38) reported a suicide rate of 1.4 per 100000 in Jamaica. Maby Mahy (FWH) (36) noted that the suicide rate in Trinidad had risen to 12 per 100000 by 1988 . He reported that the high suicide rate in Trinidad has often been attributed to a high level of suicide in females of East Indian origin. Another study from Trinidad (39) indicated that of 270 deaths by suicide between 1986 to 1990, 54\% were among people of East Indian origin and $42 \%$ involved people of African origin, but the suicide rate in East Indian females outnumbered the rate for African women by a ratio of $2: 1$. In a recent study in Jamaica (Abel W, Hickling FW, unpublished), the age-corrected suicide rate during the years 1996 to 2003 was 2.286 per 100000 .

Maby Mahy (FWH) and Griffith (40) put the rate of attempted suicide in Barbados in 1978 at 28 per 100 000, although it was later reported (36) that the rate had risen to 65 per 100000 in 1989 for that country. The latter article also noted a rate of attempted suicide of 87 per 100000 in Trinidad in 1984, and 43 per 100000 in Guyana in 1965. A study from Bermuda (41) reported an annual attempted suicide rate of 98 per 100 000. Mahy (35) concluded that the rates of attempted suicide in the English-speaking Caribbean are generally lower than those in the developed world. Clearly this is an area that needs rigorous clarification, especially in light of the extremely high suicide rates which have been reported in many white populations from different parts of the world.

\section{DISCUSSION}

The epidemiology of mental illness afflicting Caribbean people has only very recently been studied and documented. There are large gaps in our knowledge about the nature and extent of certain types of psychopathology in the people of this region. Most of the published work centers on schizophrenia and the psychoses, and this reflects the startling findings of a very large increase in risk ratios for African Caribbean people living in England compared to the white native British people. Attempts have been made by investigators in the UK to attribute this huge difference in incidence rates for schizophrenia to viral and other biological and developmental causes, but most of these theories have been disproved (29). The evidence is shifting unequivocally in favor of factors of racism and social alienation experienced by black people in the UK, and to misdiagnosis by white British psychiatrists.

The work by Hickling (28) on the psychopathology of white immigrants to the Caribbean suggests an even more profound cause for the widely different ethnic risk ratios for schizophrenia. The process of colonial enslavement and social engineering might itself have protective effects against the development of schizophrenia in white colonialists by virtue of the protective social differential provided in colonial territories, and this effect raises the possibility that social and structural community organization may play a role in the genesis of schizophrenia and other psychoses. There seems to be increasing evidence that a corollary is also true, namely, that predominantly white European societies may be profoundly schizophrenogenic, particularly for ethnic minorities.

This review of preliminary work published on Caribbean populations suggests that there is a significantly lower incidence of affective psychoses and suicide in the Caribbean than among African Caribbean people or whites living in the UK. Again, if this finding is substantiated, it may have profound implications for the understanding of the genesis of these debilitating mental health disorders, for preventive measures, and for treatment. Clearly, further work is required to document the realities of anxiety, depression, personality disorder, substance abuse and other mental disorders in children, adolescents, and the geriatric population in Englishspeaking Caribbean societies.

The process of political liberation and independence has introduced new therapeutic directions that have catalyzed the successful treatment of mental illness in these communities. New challenges that have accompanied the periods of post-colonialism and globalization have pointed the way to novel and ever-changing approaches to psychiatric care and treatment. The Caribbean represents a rich crucible for mental health discourse and study, and presents opportunities for future epidemiological research on a wide range of psychiatric conditions. This work will, I hope, help clarify the etiology of many such conditions. 


\section{REFERENCES}

1. Holliday A. A general view of the present state of lunatics and lunatic asylums in Great Britain, Ireland, and some other kingdoms. London: Thomas and George Underwood; 1828.

2. Cartwright SA. Report on the diseases and physical peculiarities of the negro race. New Orleans Medical and Surgical Journal (May 1851). In: Engelhardt AC, McCartney HY, Caplan JJ, eds. Concepts of health and disease. Reading, MA: Addison-Wesley; 1981.

3. Foucault M. (1967) Madness and civilization: a history of insanity in the Age of Reason. London: Tavistock; 1970.

4. Sashidharan SP, Francis E. Epidemiology, ethnicity and schizophrenia. In: Ahmad WIU, ed. Race and health in contemporary Britain. Buckingham, Philadelphia: Open University Press; 1993.

5. Hutchinson G, McKenzie K. What is an AfroCaribbean? Implications for psychiatric research. Psychiatr Bull. 1995;19:700-2.

6. Royes K. The incidence and features of psychosis in a Caribbean community. Soc Psychiatr. 1962; 2:1121-5.

7. Burke AW. First admissions and planning in Jamaica. Soc Psychiatr. 1974;9:39-45.

8. Hickling FW. Psychiatric hospital admission rates in Jamaica, 1971 and 1988. Br J Psychiatr. 1991;159:817-21.

9. Wessely S, Castle D, Der G, Murray R. Schizophrenia and Afro-Caribbeans. A case-control study. Br J Psychiatr. 1991;159:795-801.

10. Harrison G, Owens D, Holton A, Neilson D, Boot $\mathrm{D}$. A prospective study of severe mental disorder in Afro-Caribbean patients. Psychol Med. 1988;18: 643-57.

11. Sashidharan SP. Afro-Caribbeans and schizophrenia: the ethnic vulnerability hypothesis re-examined. Int Rev Psychiatr. 1993;5(2/3): $129-44$.

12. Hickling FW, McKenzie K, Mullen R, Murray $R$. A Jamaican psychiatrist evaluates diagnoses at a London psychiatric hospital. Br J Psychiatr. 1999;175:283-5.

13. Wing JK, Cooper JE, Sartorius N. The measurement and classification of psychiatric symptoms. London: Cambridge University Press; 1974.

14. Hickling FW, Rodgers-Johnson P. The incidence of first onset schizophrenia in Jamaica. Br J Psychiatr. 1995;167:193-6.
15. Neehall J. An analysis of psychiatric inpatient admissions from a defined geographic catchment area over a one year period. West Ind Med J. 1991;40:16-21.

16. Bhugra D, Hilwig M, Hossein D, Marceau H, Neehall J, Leff J, et al . First contact incidence rates of schizophrenia in Trinidad and oneyear follow-up. Br J Psychiatr. 1996;169:58792.

17. Mahy GE, Mallett R, Leff J, Bhugra D. First contact incidence rate of schizophrenia in Barbados. Br J Psychiatr. 1999;175:28-33.

18. Hickling FW, Rodgers-Johnson P. The prevalence of schizophrenia and affective disorders in Jamaica. West Ind Med J. 1994;43(Suppl 1): 12.

19. King M, Coker E, Leavey G, Hoare A, JohnsonSabine E. Incidence of psychotic illness in London: comparison of ethnic groups. Br Med J. 1994;309:1115-9.

20. Cochrane R, Bal S. Mental hospital admission rates of immigrants to England. Soc Psychiatry Psychiatr Epidemiol. 1989;24:2-11.

21. Kay RW. Prevalence and incidence of schizophrenia in Afro-Caribbeans. (Letter). Br J Psychiatr. 1992;160:421.

22. Sugarman PA, Crafurd, D. Schizophrenia in an Afro-Caribbean community. Br J Psychiatr. 1994;164;474-80.

23. Hutchinson G, Takei N, Sham P, et al. Morbid risk of psychotic illness in first degree relatives of white and Afro-Caribbean patients with psychosis. Br J Psychiatr. 1996;169:77680.

24. Hickling FW. Double jeopardy-mental illness in returned migrants to Jamaica. Int J Soc Psychiatr. 1991;37:44-52.

25. Hickling FW. Schizophrenia in returned Jamaican emigrants to North America and Europe. West Ind Med J. 1996;45(Suppl 12):38.

26. Burke AW. Racism and psychological disturbance among West Indians in Britain. Int J Soc Psychiatr. 1984;30:50-68.

27. Rodgers-Johnson P, Hickling FW, Irons A, Johnson BK, Irons-Morgan M, Stone GA, et al. Retroviruses and schizophrenia in Jamaica. J Mol Chem Neuropathol. 1996;28:237-43.

28. Hickling FW. The psychopathology of white mentally ill migrants to Jamaica. J Mol Chem Neuropathol. 1996;28:261-7.

29. Sharpley M, Hutchinson G, McKenzie K, Murray R. Understanding the excess of psy- chosis among the African-Caribbean population in England. Review of current hypotheses. Br J Psychiatr. 2001;178(Suppl 40):60-8.

30. Leff J, Fisher M, Betelsen A. A cross-national epidemiological study of mania. Br J Psychiatr. 1976;129:428-42.

31. Hickling FW, Rodgers-Johnson P. The prevalence of schizophrenia and affective disorders in Jamaica. West Ind Med J. 1995;44(Suppl 2): 29 .

32. Hickling FW. Psychiatric care in a general hospital unit in Jamaica. West Ind Med J. 1975; 24:76-84.

33. Goldberg D, Huxley P. Mental illness in the community: The pathway to care. London: Tavistock; 1980.

34. La Grenade-Fletcher J. Non-psychotic psychiatric morbidity in general practice: implications for service delivery and training. [Dissertation]. Mona, Kingston, Jamaica: University of the West Indies; 1990.

35. Allen EA, Gordon AI. Psychiatric morbidity and related factors in West Indian students. West Ind Med J. 1984;33(4):252-7.

36. Mahy G. Suicide in the Caribbean. Int Rev Psychiatr. 1993;5(2/3):261-9.

37. Burke AW. Clinical aspects of attempted suicide among women in Trinidad and Tobago. Br J Psychiatr. 1974;125:175-6.

38. Burke AW. Suicide in Jamaica. West Ind Med J. 1985;34:48-53.

39. Hutchinson G, Daisley H, Simmonds V, Gordon A. Suicide by poisoning: a preliminary epidemiological report. West Ind Med J. 1991; 40(Suppl 1):56-7.

40. Mahy G, Griffith EEH. Suicide and parasuicide in Barbados, 1974-1979. J Nat Med Assoc. 1980;72:8.

41. Jauhar P. Parasuicide in paradise: a three year study of suicidal behavior in Bermuda. In: Proceedings of the 12th International Congress for Suicide Prevention and Crisis Intervention; 1983 Oct $2-5$

Manuscript received on 28 September 2004. Revised version accepted for publication on 6 July 2005. 
RESUMEN Objetivos. Informar acerca de la epidemiología de trastornos mentales comunes en el Caribe angloparlante.

\section{La distribución epidemiológica de la esquizofrenia y de otros trastornos mentales comunes en el Caribe angloparlante}

Métodos. Se rastrearon las bases de datos electrónicas de MEDLINE, MEDCARIB y West Indiana usando las palabras Caribbean más psychiatry, o mental, o suicide y se eligieron y revisaron los materiales que proporcionaban datos epidemiológicos.

Resultados. La incidencia de la esquizofrenia por cada 10000 habitantes, ajustada según la edad, es de 2,09 en Jamaica y de 2,92 en Barbados. En Trinidad, la incidencia del trastorno es de 2,2 por cada 1000 habitantes. Estas tasas son menores que las notificadas en ingleses de raza blanca y más bajas, en grado estadísticamente significativo, que las tasas observadas en afrocaribeños residentes de Inglaterra, en quienes el riesgo de padecer esquizofrenia es de 16 a 18 veces mayor. Un estudio diagnóstico comparativo llevado a cabo en el Reino Unido apunta a que los errores de diagnóstico explican esta diferencia en gran medida. Tasas de incidencia relativamente bajas de trastornos afectivos, estados de ansiedad, suicidio e intento de suicidio se han notificado en Jamaica, Trinidad y Barbados.

Discusión. La mayoría de los estudios epidemiológicos publicados sobre poblaciones caribeñas se concentran en la esquizofrenia debido al elevado riesgo de padecer este trastorno que se observa en afrocaribeños residentes de Inglaterra, por comparación con los ingleses de raza blanca. Hay cada vez más indicios de que la causa radica en el racismo y en la marginación social que sufre la población negra radicada en el Reino Unido, y en los diagnósticos equivocados emitidos por psiquiatras blancos. Los estudios sobre el papel de la esclavitud y la ingeniería social en las colonias llaman la atención a la posibilidad etiológica de que la organización social y estructural de la comunidad desempeñe un papel en el origen de la esquizofrenia. Por consiguiente, el Caribe representa un estupendo crisol para la investigación de la distribución epidemiológica y las causas de los trastornos mentales.

Palabras clave Epidemiología; Caribe; salud mental.

Everyone is a house with four rooms: physical, mental, emotional, and spiritual. Unless we go into every room every day, even if only to keep it aired, we are not a complete person.

Rumer Godden, English novelist (1907-1998) 